\title{
Analisis Pemanfaatan Media Pembelajaran TIK Dalam Meningkatkan Pemahaman Siswa Pada Mata Pelajaran PAI
}

\author{
Fitri Oktavia ${ }^{1}$, Alfurqan ${ }^{2}$ \\ Jurusan Ilmu Agama Islam, Fakultas Ilmu Sosial, Universitas Negeri Padang, Indonesia ${ }^{1,2}$ \\ fitrioktavia1997@gmail.com ${ }^{1}$, alfurqan@ fis.unp.ac.id ${ }^{2}$
}

\begin{abstract}
The purpose of this study to describe the effectiveness of the use of ICT learning media in increasing student understanding of islamic Religious Education learning at SMP N 1 Lembang Jaya and the contraints experienced by teacher in the effective use of ICT based media in Islamic Education Learning. This type of research is qualitative with descriptive methods. Based on theresearch, the result of the effectiveness of the use of ICT based learning media in increasing student understandingof islamic Religious Education Learning at SMP N 1 Lembang Jaya have not been fully effective. Based on indicators of measuring the effectiveness of ICT learing media that of all indicators only $50 \%$ are effective. This is evidenced by the findings of researchers of measuring the effectiveness of ICT based learning media such as, student involvement, the acuracy of media selection, being able to make students understand abstract things, the availability of media, can provide a learning experience which means that it has not been effective. There are obstacles in making ICT based learning media effevtive in increasing student understanding of Islamic Religious Education learning at SMP N 1 Lembang Jaya, namely contraints that come from outside due to the lack of availability of media so that its use is limited as well as electricity that suddenly went out. .
\end{abstract}

Keywords: Effectiveness, Learning Media ICT, Leraners Understanding

\section{Pendahuluan}

Proses pendidikan merupakan kegiatan yang berkaitan dengan pembelajaran, kurikulum pendidikan, tenaga kependidikan yang profesional, fasilitas atau sarana dan prasarana, anggaran dan lain sebagainya (Hobir, A., 2019). Kemampuan yang dimiliki siswa akan lebih terangsang dengan adanya media pembelajaran sebagai alat bantu proses pembelajaran (Anam, 2020). Seperti yang diungkapkan Oemar Hamalik dalam (Fatah Syukur, 2005) bahwa media merupakan teknik yang digunakan untuk mengefektifkan komunikasi antara guru dan siswa dalam proses pembelajaran. Pada era globalisasi, kehadiran teknologi memiliki peranan penting dalam menunjang kegiatan pembelajaran. Peranan teknologi sudah sedemikian menonjol dalam dunia pendidikan. Dengan kemajuan ilmu teknologi yang canggih media berperan membantu guru dalam menyampaikan materi kepada siswa agar lebih mudah di pahami oleh siswa. Seiring dengan perkembangan teknologi, banyak media yang bisa digunakan untuk mendorong peningkatan kemampuan siswa dalam memahami suatu pembelajaran seperti Teknologi Komputer/laptop, LCD Proyektor, Teknologi Internet, Teknologi multimedia, Android, dan lain sebagainya (Masdiyah Nuris, 2018).

Teknologi Informasi dan Komunikasi merupakan sarana prasarana berupa hardware, userware, dan software yang di dalamnya terdapat metode untuk menerima, mengumpulkan, mengolah, menafsirkan, mengorganisasikan, menyimpan dan 
menggunakan data. Media pembelajaran Teknologi Informasi dan Komunikasi merupakan alat teknologi berupa (hardware, software, useware) yang digunakan untuk mengumpulkan, menerima, mengirimkan, mengolah, menafsirkan, dan menyimpan data yang digunakan dalam proses pembelajaran guna memperoleh informasi yang berkualitas (Widayanti, 2017). Hadirnya media pembelajaran Teknologi Informasi dan Komunikasi diharapkan bisa membantu guru menyampaikan informasi atau isi dari pelajaran tersebut kepada siswa dengan cepat dan mudah, sehingga siswa lebih mudah memahami materi pelajaran dan siswa lebih mendapatkan pengalaman belajar sehingga mereka bisa mengimplementasikan dalam kehidupan nyata (Masdiyah Nuris, 2018). Apabila dilihat secara umum pembelajaran Pendidikan Agama Islam di sekolah guru cenderung menggunakan metode ceramah dan bersifat menghafalkan, hal ini menuntut peserta didik mesti memiliki ingatan yang kuat guna menghafalkan materi pembelajaran.

SMP N 1 Lembang Jaya telah menyediakan fasilitas untuk menunjang kegiatan pembelajaran guna mencapai tujuan yang telah ditetapkan. Fasilitas yang disediakan sekolah ialah fasilitas yang sudah disesuaikan dengan perkembangan zaman seperti media pembelajaran berbasis TIK yaitu Teknologi Komputer, Teknologi Internet, dan LCD Proyektor. Kehadiran serta pemanfaatan media pembelajaran TIK diharapkan dapat meningkatkan pemahaman siswa pada pembelajaran Pendidikan Agama Islam, namun hal tersebut belum sepenuhnya tercapai, terdapat fenomena dimana masih ada siswa yang mengalami kesulitan dalam memahami materi pembelajaran Pendidikan Agama Islam. Berdasarkan hasil observasi awal terhadap pembelajaran Pendidikan Agama Islam salah satunya dari hasil belajar sumatif yaitu dari nilai yang diperoleh oleh siswa pada pelaksanaan UTS (Ujian Tengah Semester) masih terdapat 50\% siswa yang belum mencapai batas Kritera Ketuntasan Minimum (KKM) yaitu 75. Berdasarkan dari paparan di atas peneliti merasa perlu melakukan penelitian dengan judul "Analisis Pemanfaatan Media Pembelajaran TIK Dalam Meningkatkan Pemahaman Siswa Pada Mata Pelajaran PAI"

\section{Tinjauan Pustaka}

Efektif dalam bahasa inggris berasal dari kata effectivee yang memiliki arti berhasil atau berhasilnya sesuatu yang dilakukan. Efektivitas dalam KBBI berasal dari kata efektif yang berarti efek, akibat, pengaruh atau membawa hasil. Efektivitas juga bisa didefenisikan sebagai sesuatu yang berpengaruh atau menimbulkan akibat dan berhasilnya suatu usaha atau tindakan yang dilakukan. Dalam hal ini dapat dilihat sebagai suatu efektivitas dari tercapainya tujuan yang telah ditentukan sebelumnya. Srcara umum efektivitas menunjukkan seberapa jauh ketercapaian tujuan yang telah ditentukan (Radhita, 2018)

Indikator atau kriteria pengukuran efektifnya sebuah media pembelajaran berbasis TIK menurut (Smaldino, 2011) adalah sebagai berikut :

1) Keterlibatan siswa, dalam menggunakan media TIK harus dapat melibatkan siswa ketika pembelajaran sedang berlangsung.

2) Kesiapan dalam pemanfaatan media pembelajaran. 
3) Ketepatan pemilihan media dengan materi pembelajaran sehingga mewujudkan tercapainya tujuan pembelajaran.

4) Bahasa yang digunakan disesuaikan dengan usia siswa

5) Media pembelajaran TIK mampu memahami hal-hal yang abstrak.

6) Ketersediaan/kelengkapan media pembelajaran.

7) Media TIK yang digunakan mampu membantu mengaitkan konsep dengan realita.

8) Media berbasis TIK yang digunakan memberikan pengalaman belajar yang berarti.

Kata media merupakan bentuk jamak dari kata medium yang secara harfiah memiliki arti "perantara, penengah, atau pengantar" (Dirman dan cicih juarsih, 2014). Manfaat media secara umum ialah memperlancar komunikasi atau interaksi antara guru dengan siswa dalam proses pembelajaran sehingga pembelajaran akan lebih efektif. Selain manfaat secara umum ada beberapa manfaat media secara khusus yaitu menarik perhatian siswa, sehingga dapat menumbuhkan motivasi belajar siswa, memungkinkan tercapainya tujuan pembelajaran karena siswa lebih mudah memahami makna materi, beragamnya metode pembelajaran sehingga siswa tidak cepat bosan, dan aktivitas siswa akan lebih banyak selama kegiatan pembelajaran, tidak hanya mendengar tetapi juga bisa mengamati, melakukan dan medemonstrasikan (Sutikno, 2004).

Pendidikan Agama Islam menurut (Mahmud dkk, 2015) ialah pembentukan karakter siswa agar sesuai dengan Al-Quran dan As-Sunnah melalui usaha yang dilakukan oleh seorang pendidik. Jadi, pembelajaran Pendidikan Agama Islam ialah pembelajaran yang dilakukan dimana tujuannya menghasilkan manusia yang beriman, bertakwa, dan membangun peradaban bangsa yang bermartabat. Pembelajaran Pendidikan Agama Islam merupakan proses belajar yang membentuk karakter siswa sesuai dengan Al-Quran dan As-Sunnah sehingga terciptanya situasi dan kondisi masyarakat yang sejahtera dalam kehidupan di alam semesta yang rahmatan lil 'alamin.

Pendidikan Agama Islam memiliki tujuan-tujuan yang harus dicapainya menurut Widayanti, (2017). Tujuan pertama yaitu tujuan umum, dimana Pendidikan Agama Islam bertujuan mendidik manusia untuk meningkatkan kualitas diri sesuai yang terdapat dalam Al-Qur'an dan hadist. Al-Quran telah menyebutkan secara jelas tujuan diciptakannya manusia ialah untuk beribadah kepadaNya. Hal ini terdapat dalam AlQur'an surat Az-Zariyat ayat 56 yang berbunyi :

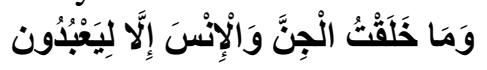

Artinya : Dan aku tidak menciptakan manusia dan jin melainkan untuk beribadah kepada-Ku (Q.S Az-Zariyat : 56).

Tujuan kedua itu secara khusus Pendidikan Agama Islam memiliki tujuan yang disesuaikan dengan pertumbuhan dan perkembangan anak sesuai dengan jenjang pendidikan yang di laluinya. Setiap jenjang pendidikan itu memiliki tujuan Pendidikan Agama Islam yang berbeda-beda.

Kehadiran teknologi dalam proses pembelajaran menjadi sebuah bagian terpenting guna menunjang proses pembelajaran. Teknologi Informasi dan Komunikasi merupakan aspek yang berkaitan dengan penggunaan teknologi untuk memproses, memanipulasi, mengelola, dan mentransfer informasi antar media.Teknologi Informasi 
dan Komunikasi didefenisikan sebagai seperangkat peralatan dan sumber daya teknis yang digunakan untuk berkomunikasi, membuat, menyebarkan, menyimpan dan mengelola informasi. Teknologi ini berupa teknologi komputer/laptop, internet, teknologi penyiaran dan telepon (Widayanti, 2017). Peranan Teknologi Informasi dan Komunikasi sebagai media pembelajaran, kita dapat melihat lima perspektif yaitu, media sebagai teknologi, media sebagai guru atau pembimbing, media sebagai penggerak pembelajaran, media sebagai media sosial, media sebagai alat psikologis untuk berfikir dan memecahkan masalah.

Penggunaan media pembelajaran berbasis Teknologi Informasi dan Komunikasi dalam proses pembelajaran dapat menimbulkan keinginan dan minat baru, merangsang kegiatan pembelajaran serta membangkitkan motivasi. Selain itu juga dapat meningkatkan pemahaman, memudahkan penyampaian pesan, tidak sulit dalam menafsirkan serta memperbanyak informasi. Menurut (Smaldino, 2011) Efektivitas pemanfaatan media pembelajaran TIK dapat dilihat dari sejauh mana tercapainya indikator efektivitas pemanfaatan media pembelajaran sebagai upaya untuk meningktakan pemahaman siswa pada pembelajaran Pendidikan Agama Islam yang telah dirumuskan.

Penelitian terdahulu telah dilakukan tentang pemanfaatan media TIK Pada seluruh Sekolah Menengah Atas Negeri se-Kabupaten Pamekasan. Rasyidi (2012). Penelitian tersebut diperoleh kesimpulan bahwa pemanfaatan media Teknologi Informasi dan Komunikasi sudah berjalan efektif. Penelitian selanjutnya yang dilakukan oleh Jamiludin tentang Efektivitas Pemanfaatan Media Berbasis Komputer Dalam Pembelajaran Sejarah. Hasil penelitian menunjukkan bahwa pemanfaatan media pembelajaran TIK yang khususnya berbasis komputer belum berjalan efektif.

\section{Metode Penelitian}

Jenis penelitian ini menggunakan pendekatan kualitatif dengan metode deskriptif, yaitu penelitian yang dilakukan dengan tujuan mendapatkan informasi yang sesuai dengan keadaaan yang sebenarnya (Sugiyono, 2012). Informan dalam penelitian ini ialah guru PAI yang mengajar kelas VIII, siswa pada kelas VIII SMP Negeri 1 Lembang Jaya. Instrumen penelitian adalah sesuatu yang dapat digunakan sebaagi alat bantu dalam mengumpulkan data secara terarah oleh peneliti. Adapun dalam penelitian kualitatif instrumen utama adalah peneliti itu sendiri, dalam arti peneliti terjun langsung kelokasi untuk berinteraksi dengan informan yang sudah peneliti pilih yang berada di SMP N 1 Lembang Jaya.

Peneliti melakukan pengamatan langsung untuk menemukan fakta-fakta di lapangan dan mengumpulkan dokumen yang dibutuhkan yaitu data-data pembelajaran PAI yang menggunakan media berbasis TIK di SMP N 1 Lembang Jaya. Subjek wawancara dalam penelitian ini ialah guru PAI, siswa kelas VIII SMP N 1 Lembang Jaya. Data yang dikumpulkan bersifat kualitatif dan teknik analisis menggunakan teknik kualitatif. Adapun teknik analisis data kualitatif merupakan analisis yang memerlukan tiga komponen yaitu reduksi data, sajian data, serta penarikan kesimpulan. Setelah peneliti melakukan pemilahan, penyederhanaan, penggolongan data dapat ditarik kesimpulan yang benar-benar bisa dipertanggungjawabkan. 


\section{Hasil dan Pembahasan}

Berdasarkan data yang diperoleh, hasil penelitian dapat diuraikan sebagai berikut :

a. Efektivitas Pemanfaatan Media Pembelajaran Teknologi Informasi dan Komunikasi

Penulis menggunakan teori Smaldino, dimana terdapat delapan indikator sebagai tolak ukur efektivitas, yaitu keterlibatan siswa, kesiapan dalam pemanfaatan media, ketepatan dalam pemilihan media, kesesuaian bahasa dengan peserta didik, media pembelajaran berbasis Teknologi Informasi dan Komunikasi mampu memahami hal-hal yang abstrak maupun konkret. Kelengkapan/ketersediaan media pembelajaran, dapat membantu mengaitkan konsep dengan realita (kontekstual), media yang digunakan dapat memberikan pengalaman belajar yang berarti.

Keterlibatan siswa merupakan hal yang sangat penting dalam proses pembelajaran, dimana siswa akan merasa lebih percaya diri dan berani untuk mencoba sesuatu yang menjadi pendorong semangat siswa dalam pembelajaran.Siswa tidka akan bosan dan jenuh dengan cara guru mengajar, sehingga materi yang diajarkan guru akan terserap dengan sempurna oleh siswa (Wungguli, D \& Yahya 2020). Keterlibatan siswa dalam proses pemanfaatan media berbasis TIK sebagai upaya meningkatkan pemahaman siswa pada mata pelajaran PAI di SMP N 1 Lembang Jaya dapat dikatakan belum efektif. Hal ini dilihat dari hanya sebagian kecil siswa yang ikut terlibat dalam proses pemanfaatan media dan cenderung lebih bersemangat dibanding mereka yang tidak terlibat. Hal ini dibuktikan dari hasil wawancara dengan guru PAI sebagai berikut:

"Dalam pemanfaatan media pembelajaran berbasis TIK kadang-kadang ada siswa yang dilibatkan dalam pengoperasiannya seperti melakukan pemasangan kabel proyektor ke laptop, namun hanya beberapa orang saja yang terlibat, dan siswa yang ikut terlibat dalam pemanfaatan media ini lebih bersemangat dalam proses pembelajaran dibanding yang tidak”. (Wawancara, 22 Maret 2021)

Kurangnya keterlibatan siswa pada proses pembelajaran terkait dengan pemanfaatan media pembelajaran TIK tidak hanya dipandang dari segi guru saja, penulis juga melihat dari sudut pandang siswa. Dimana terdapat tiga orang siswa kelas delapan yang menjadi sumber data penulis yaitu Sherly, Aisya dan Vania. mereka mengatakan bahwa guru tidak selalu melibatkan siswa dalam pemanfaatan media berbasis TIK dan hanya sebagian kecil yang terlibat. Mereka yang ikut terlibat cenderung lebih bersemangat dalam pembelajaran.

Tujuan pemanfaatan media pembelajaran berbasis TIK ialah agar siswa menemukan konsep materi pelajaran yang sebelumnya siswa tidak mengetahuinya. Dengan adanya media pembelajaran yang berbasis TIK dapat meningkatkan motivasi siswa sehingga siswa lebih aktif dan kreatif dalam pembelajaran (Sutisna, E., Novita, L., \& Iskandar, 2020).

Kesiapan dalam memanfaatakan media dalam proses pembelajaran akan mempengaruji hasil belajar yang akan diperoleh oleh siswa setelah selsesai belajar. Kesiapan yang dimaksud disini ialah bagaimana guru memiliki kesiapan untuk 
menyampaikan materi menggunakan media berbasis TIK dan juga kesiapan siswa untuk menerima pembelajaran melalui media berbasis TIK. Kesiapan dalam pemanfaatan media berbasis Teknologi Informasi dan Komunikasi dalam pembelajaran PAI di SMP N 1 Lembang Jaya kelas delapan dapat dikatakan sudah efektif. Hal ini dapat dilihat dari hasil wawancara yang peneliti lakukan dengan guru PAI dan siswa kelas delapan SMP N 1Lembang Jaya, dimana guru PAI mengatakan bahwa:

"Untuk pemanfaatan media TIK ini saya sudah menyiapkan apa saja yang akan di gunakan dalam proses pembelajaran yaitu berupa materi, Slide video jika akan menggunakan video beserta peralatan yang lengkap"

Kesiapan dalam pemanfaatan media berbasis TIK ini tidak hanya dilihat dari segi guru saja, peneliti juga melihat adanya kesiapan dari siswa untuk menerima pembelajaran menggunakan media pembelajaran berbasis TIK. Peneliti melakukan wawancara dengan siswa kelas delapan yaitu Pinky, Rahmatul Zikri, Nilam, dan Sherly. Mereka mengatakan bahwa kami menyiapkan diri dari rumah untuk menerima pembelajaran dari guru disekolah menggunakan media pembelajaran TIK.

Indikator ini melihat bagaimana media yang digunakan oleh guru PAI pada saat proses pembelajaran sesuai dengan materi yang diajarkan. Pemilihan media masih dikatakan kurang efektif. Hal ini bisa dibuktikan dari hasil wawancara dengan guru PAI dan siswa kelas delapan serta observasi yang peneliti lakukan secara langsung, dimana guru PAI mengatakan bahwa dalam proses pelaksanaan pembelajaran di kelas memakai tampilan media power point dan pada saat penampilannya ada yang tidak sesuai dengan poin-poin materi yang akan diajarkan. Begitu juga dengan yang dikatakan oleh siswa kelas delapan yaitu Sherly, Vania dan Nilam yang mengatakan kurang sesuainya power point yang diajarkan dengan materi pembelajaran.

Pemanfaatan media pembelajaran berbasis Teknologi Informasi dan Komunikasi (TIK) harus memerhatikan penggunaan bahasa, artinya bahasa yang digunakan harus disesuaikan dengan usia siswa yang diajarkan. Kesesuaian bahasa dalam pemanfaatan media berbasis Teknologi Informasi dan Komunikasi sebagai upaya meningkatkan pemahaman siswa pada mata pelajaran PAI sudah efektif. Hal ini dapat dilihat dari hasil wawancara dengan guru PAI dan siswa kelas delapan dimana guru PAI mengatakan bahwa:

"Saat proses pembelajaran berlangsung menggunakan media berbasis TIK tidak ada lagi siswa yang bertanya terkait dengan penggunaan bahasa dan dapat diakatakan bahwa pemilihan bahasa sudah sesuai dengan usia siswa".

Hal itu juga diungkapkan oleh siswa kelas delapan yaitu Sherly, Rahmatul Zikri, dan Pinky mereka mengatakan bahasa yang digunakan guru sudah sesuai dengan usia kami dan kami pun mudah dalam memahamimateri yang diberikan.

Pemanfaatan media pembelajaran berbasis Teknologi Informasi dan Komunikasi harus mampu mengantarkan siswa memahami hal-hal yang bersifat abstrak. Sebab salah satu fungsi media ialah memudahkan dalam proses penyampaian informasi dari guru kepada siswa seperti dalam menyampaikan hal- 
hal yang bersifat abstrak. Pemanfaatan media berbasis TIK pada mata pelajaran PAI di SMP N 1 Lembang Jaya belum mampu mengantarkan siswa untuk memahami hal-hal yang bersifat abstrak. Berdasarkan hasil wawancara peneliti dengan sumber informasi yaitu guru PAI dan siswa kelas delapan. Hasil wawancara dengan guru PAI, beliau mengatakan bahwa terkait dengan hal-hal yang bersifat abstrak masih lebih dari sebagian siswa yang perlu penjelasan ulang terhadap apa yang ditampilkan guru didepan. Begitu juga dengan hasil wawancara peneliti dengan siswa kelas delapan yaitu Vania, Rahmatul Zikri, dan Sherly mereka mengatakan masih banyak siswa yang butuh penjelasan lebih lanjut terhadap apa yang ditampilkan oleh guru di depan kelas terkait materi yang diajarkan.

Ketersediaan media dalam proses pembelajaran yang akan mengukur efektivitas pemanfaatan media tersebut. Ketersediaan media pembelajaran berbasis Teknologi Informasi dan Komunikasi (TIK) di SMP N 1 Lembang Jaya masih kurang mencukupi. Hal ini dilihat dari belum adanya LCD Proyektor yang terpasang di setiap kelas dan pemakaiannya harus bergantian serta keadaan colokan yang kurang baik sehingga sulit untuk menggunakan media pembelajaran berbasis TIK.

Pemanfaatan media pembelajaran berbasis Teknologi Informasi dan Komunikasi (TIK) dalam pembelajaran bisa dikatakan efektif apabila dapat membantu siswa mengaitkan suatu konsep dengan suatu kenyataan yang bisa di lihat dalam kehidupan sehari-hari. Kehadiran media pembelajaran berbasis Teknologi Informasi dan Komunikasi dalam proses pembelajaran sudah efektif dalam membantu siswa untuk dapat mengaitkan konsep-konsep yang ada dengan kenyataan yang ada. Hal ini dibuktikan dari hasil wawancara peneliti dengan narasumber dan juga berdasarkan observasi yang peneliti lakukan.Dari hasil wawancara dengan guru PAI menunjukan bahwa siswa sudah mampu untuk mengaitkan antara konsep dengan realita yang ada dalam kehidupan. Hal ini juga dikatakan oleh siswa kelas delapan yaitu Sherly, Pinky, dan Nilam, dimana mereka mengatakan bahwa konsep yang diajarkan guru sudah mampu kami kaitkan dengan kehidupan nyata atau realita.

Indikator pemanfaatan media pembelajaran yang sudah ditunjang oleh kemajuan teknologi harus dapat memberikan pengalaman belajar yang berarti kepada siswa setelah mereka selesai belajar. Pemanfaatan media pembelajaran berbasis Teknologi Informasi dan Komunikasi belum efektif dalam memberikan pengalaman belajar yang berarti kepada siswa. Hal ini bisa di lihat dari hasil yang peneliti peroleh saat melakukan wawancara dan observasi di SMP N 1 Lembang Jaya. Hasil wawancara dengan guru PAI, yaitu siswa belum mendapatkan pengalaman belajar yang berarti setelah menggunakan media pembelajaran TIK, dimana masih ada siswa yang tidak suka, serta masih sedikit memahami materi pelajaran yang diberikan. Hal itu juga diungkapkan oleh siswa kelas delapan yaitu Rahmatul Zikri, Sherly, dan Vania. Mereka mengatakan bahwa ada dari mereka yang tidak suka belajar dengan media dan masih ada yang tidak bisa menjawab pertanyaan yang diberikan guru setelah pembelajaran selesai. 


\section{Kendala Dalam Mengefektifkan Pemanfaatan Media Pembelajaran Berbasis Teknologi Informasi dan Komunikasi (TIK)}

Pengefektifan Pemanfaatan Media pembelajaran berbasis Teknologi Informasi dan Komunikasi (TIK) pada mata pelajaran PAI ditemukan beberapa kendala yaitu masih terbatasnya LCD Proyektor, seharusnya alat ini sudah terpasang disetiap ruang kelas, sehingga kadang-kadang berebutan atau bergantian menggunakannya, listrik yang tiba-tiba mati, dan keadaan colokan yang rusak. Sehingga kendala tersebut menghambat efektifnya pemanfaatan media pembelajaran berbasis Teknologi Informasi dan Komunikasi (TIK). Hal ini dapat dilihat dari hasil observasi dan wawancara dengan informan. Hasil wawancara dengan guru PAI yaitu beliau mengatakan bahwa kurangnya fasilitas media seperti tidak adanya LCD Proyektor yang terpasang disetiap kelas, colokan yang rusak. Hal ini juga di katakan oleh siswa kelas delapan yaitu Sherly, Vania dan Nilam, mereka mengatakan bahwa guru tidak selalu menggunakan media karena LCD Proyektor yang tidak ada disetiap kelas dan harus meminta arus listrik kelokal sebelah karena keadaan colokan yang rusak.

\section{Simpulan}

Pemanfaatan media pembelajaran berbasis Teknologi Informasi dan Komunikasi (TIK) dalam meningkatkan pemahaman siswa pada mata pelajaran PAI dapat dikatakan belum berjalan efektif, ini dilihat dari ketercapaian indikator efektivitas yang diungkapkan oleh Smaldino yaitu ada delapan indikator seperti keterlibatan siswa, kesiapan dalam pemanfaatan media, ketepatan dalam pemilihan media, kesesuaian bahasa dengan peserta didik, media pembelajaran berbasis Teknologi Informasi dan Komunikasi mampu memahami hal-hal yang abstrak maupun konkret., Kelengkapan/ketersediaan media pembelajaran, dapat membantu mengaitkan konsep dengan realita (kontekstual), media yang digunakan dapat memberikan pengalaman belajar yang berarti. Dari delapan indikator tersebut hanya tiga indikator yang dapat dikatakan efektif dan selebihnya belum mencapai tingkat efektif.

Hambatan atau kendala yang terjadi di SMP N 1 Lembang Jaya masih terbatasnya LCD Proyektor, seharusnya alat ini sudah terpasang disetiap ruang kelas, sehingga kadang-kadang berebutan atau bergantian menggunakannya, listrik yang tibatiba mati, dan keadaan colokan yang rusak. Sehingga kendala tersebut menghambat efektifnya pemanfaatan media pembelajaran berbasis Teknologi Informasi dan Komunikasi (TIK).

\section{Referensi}

Anam, K. (2020). Pengaruh Media Pembelajaran Terhadap Minat Belajar Siswa Pada Mata Pelajaran PAI di SMP Bani Muqiman Bangkalan. Jurnal Pendidikan Islam.

Dirman dan cicih juarsih. (2014). Kegiatan Pembelajaran Yang Mendidik. Rineka Cipta.

Fatah Syukur. (2005). Teknologi Pendidikan, . rasail. 
Hobir, A., \& K. (2019). MENJADI GURU PROFESIONAL DALAM MENGAHADAPI DINAMIKA PERSAINGAN GLOBAL. Jurnal Pendidikan Dan Sosial Keagamaan.

mahmud dkk. (2015). pendidikan agama islam berbasis multietnik. Deepublish. Masdiyah Nuris. (2018). Penggunaan Media Berbasis Teknologi Informasi dan Komunikasi Dalam Pembelajaran Pendidikan Agama Islam. STAIN parepare.

Radhita, siti. (2018). Efektivitas Pemanfaatan Media LCD Proyektor Pada Pembelajaran Figh di MTs N 2 Banda Aceh. 67.

Smaldino, S. E. dkk. (2011). Instructional Technology \& Media For Learning (A. Rahman (ed.); kesembilan). KENCANA.

sobri sutikno. (2004). Menuju Pendidikan Bermutu. NTP Press.

Sugiyono. (2012). Metode Penelitian Pendidikan Pendekatan Kuantitatif, Kualitatif, dan R\&DSugiyono. 2012. "Metode Penelitian Pendidikan Pendekatan Kuantitatif, Kualitatif, dan R\&D.” Metode Penelitian Pendidikan Pendekatan Kuantitatif, Kualitatif, dan R\&D. https://doi.org/1. In Metode Penelitian Pendidikan Pendekatan Kuantitaif, Kualitatif, dan R\&D.

Sutisna, E., Novita, L., \& Iskandar, M. I. (2020). PENGGUNAAN MEDIA PEMBELAJARAN BERBASIS TEKNOLOGI, INFORMASI, DAN KOMUNIKASI DALAM MENINGKATKAN HASIL BELAJAR SUBTEMA LINGKUNGAN TEMPAT TINGGALKU. Jurnal Ilmiah Pendidikan.

Widayanti. (2017). Pemanfaatan media pembelajaran pendidikan agama islam berbasis teknologi dan informasi untuk peningkatan kualitas bacaan al-quran. IAIN Salatiga.

Wungguli, D. \& Y. (2020). Pengaruh penggunaan media berbasis information and comunication (ICT) Terhadap Hasil Belajar Siswa Pada Materi Dimensi Tiga. Jambura Journal Of Mathematics Education. 